Article

\title{
RURAL CHINA'S INVISIBLE WOMEN: A FEMINIST POLITICAL ECONOMY APPROACH TO FOOD SECURITY
}

\author{
LANYAN CHEN \\ Nippissing University. North Bay, Ontario.
}

\section{Acknowledgement}

The author would like to acknowledge the assistance of her Chinese graduate students during the field research, the International Gender and Trade Network for its financial support, two anonymous reviewers for their expert comments and Elaine Coburn for her valuable editorial suggestions.

\section{Biographical Note \\ Lanyan Chen is an Associate Professor of Social Welfare and Social Development at Nipissing University in North Bay, Ontario. She obtained her doctorate from the University of British Columbia and taught sociology and international development at University of Victoria and Simon Fraser University before she was appointed as UNIFEM Gender Advisor in Northeast Asia in 1998 to set up the UNIFEM office in Beijing. Her published research includes Gender and Chinese Development: Towards an Equitable Society (2008, Routledge) and articles both in English and Chinese in areas of women's cooperatives, poverty reduction and micro-finance, health policy reforms, AIDS prevention and migration in China in Oxford Handbook Series, Feminist Economics, Development and Change, and Canadian Journal of International Development. She can be reached at lanyanc@nipissingu.ca.}

\begin{abstract}
From a feminist political economy perspective, this article examines two recent trends in agricultural production in china likely to exacerbate gender inequalities that have been growing since the 1980 s economic reforms. First, rural women are looking after land contracted to the family to grow food for the family while men are engaging in trade, marketing agricultural products and/or employment in cities. Second, some men have found opportunities, opened up by the government's land transfer policy, to create agricultural farms by contracting land from other villagers. Women work for these farms as wage laborers. These trends reinforce male-dominated systems of food provision and pose threats to "food security" in China's countryside, meaning inadequate access to diverse, valued foods that promote good health. These threats are particularly acute as gender disparities in rural areas increase. I conclude that existing examples of agricultural workers' cooperatives are important prefigurative practices. Such cooperatives could serve as places where women cooperators' voices are strengthened against patriarchal policies in the household and in communities. This has important implications for food security.
\end{abstract}




\section{Keywords \\ gender inequality, food provision, agricultural production and distribution, grain storage, social reproduction, rural women, cooperatives, China, feminist political economy}

Rural women in China are often left alone working on their families' contracted land. These women are known as "liushou funu", "women staying behind on land". The land they are working on is most likely their husbands' families' contracted land. At the same time, these women do the lion's share of reproduction, while men have moved to urban areas for jobs. They bare the brunt of coping with the negative outfall of the daunting "three problems" in the countryside: slower growth of farmers' income compared to rising costs of living and of social services; obsolete agricultural production that is no longer competitive at the world level; and underdeveloped rural areas given an overall urban biased economic orientation by the Chinese state (Chen 2008: 19).

In this article, I argue that these problems are particularly acute given strong gender differences in rural farming and rural incomes. These differences are rooted in a long history of gender inequalities in China. But these inequalities have been exacerbated by changes in the world political economy and fostered by Chinese state policies that fail to account for and give voice to rural women, who engage in vital productive and reproductive labour. This study uses official Chinese state information and academic analysis supported by quantitative survey data and my own more qualitatively based field research in four provinces: Guangdong and Fujian in the southeast coast and Hebei and Shandong in central China. I examine recent discussions of food security - meaning access to diverse, valued food contributing to healthy living - from a feminist political economy perspective to show how gender inequality in rural China exacerbates food insecurity. In so doing, I highlight the ways that Chinese rural development strategies neglect women's role in agricultural production and food security.

This examination informs policy changes in the final discussion of a balanced approach to rural development. But it is not strictly a policy focus. Instead I am arguing for political changes to strengthen the voice of rural women, arguing that expanding agricultural cooperatives is one critical way of bringing about changes that improve women's wellbeing. These rural cooperatives will enable women cooperators to have a stronger role within their households and more broadly in society, which is critical to fighting off risks to food security in their families, sharing more equitably in social welfare and generally speaking bringing about greater well-being for Chinese rural women and their families. 


\section{Male-Dominated Systems of Food Provision: Agricultural Policy since the Great Leap Forward}

Chinese scholars (Zhang Xiaotao and Wang Yang 2009: 3-5) have suggested that food provision involves the organization of agricultural production and rural and urban industries that use agricultural products. But they observe that food provision also includes food processing industries and distribution mechanisms through commerce and international trade. In other words, they suggest that agricultural production and distribution form a basis for the Chinese economy; this economy is not only national but embedded in world-wide capitalist relations. The entry of China into the World Trade Organization (WTO) in 2001, for instance, is one way that China is formally integrated into global market economics. Yet this is capitalism with Chinese characteristics. While no longer a planned economy with near-total government control, China still retains strong state controls alongside corporatization and marketization measures adopted in the 1980s to improve productivity (Zhang Xiaotao and Wang Yang 2009: 9; Wang Guofeng 2009: 45).

\section{The 1950s and 1960s: From an Agricultural to an Industrial Economy}

For more than half a century, ever since the Great Leap Forward movement in the late 1950s, government control in China has been driven by a strategy centered on industrialization and urbanization, processes that depend upon plundering agriculture and exploiting farmers. Initially, the government brought agriculture under control by establishing the state as the sole supplier and customer of agricultural production. The establishment of the systems of communes and the Agricultural Supply and Sales Cooperatives helped the government minimize the costs of agricultural production and distribution. At the same time, the government adopted a food rationing system and a household registration system to control the size of urban populations dependent on the government for food, rather than subsistence. These strategies maximized the grain supply for industrial uses and minimized human consumption of food.

Farmers received small land holdings during the land reforms in the early 1950s. These farmers were organized into cooperatives mostly on a voluntary basis. In the three years leading up to the Great Leap Forward in 1958, they were encouraged to merge their cooperatives into far larger collectives, named People's Communes. This collectivization movement made farmers members of the communes without rights to directly control the use of land and decide the use of harvests. Instead, control was exercised through a quota system set up by the government. The communes were incorporated as the lowest level of the state administration, making it easier for the government to control agricultural production and food distribution, as the number of producers was reduced from 0.15 billion small farm households to 50,000 amalgamated communes (Zhang Xiaotang and Wang Yang 2009: 64).

The government used the Agricultural Supply and Sales Cooperatives throughout the 
country to provide productive materials, including fertilizers and seeds, and to monopolize the collection of grain quotas from each commune. In this way, the government established a "scissors' pricing" system, namely, suppressing the prices of agricultural products and the costs of distribution so as to subsidize industrial production. As Deng Yiming et al (1993: 5, sited by Zhang Xiaotao and Wang Yang 2009: 71) reveal, from 1953 to 1962, this system enabled the government to collect an additional 120.86 million tons grain over and above what had collected nine years earlier, a 41 percent increase. This enabled China to transition from an economy centered on agriculture, representing 50.5 percent of the GDP in 1952, to an industrial economy with agriculture reduced to 32.8 percent of the GDP by 1976. China's first phase of industrialization was thus based largely on crude accumulation from agriculture.

Further, the government regulated the size of the non-agricultural population in accordance with the needs of industrial production and the conditions of harvests. For instance, during the Cultural Revolution the state sent urban youth and government employees to the countryside. This created further burdens for farmers, who suddenly had to feed those sent to rural areas but on the same amount of land. The increased exploitation of farmers by the state did not give rise to open conflicts, however, partly because the communes, as farmers' collectives, served as a buffer that obscured the government's manipulation and control over agricultural production.

\section{The 1970s and 1980s: From Communes to the Ten Policies to Improve the Rural Economy}

The communes operated collectively, integrating production with social reproduction. They were guided by equalitarian principles, namely, equalizing income through a work point system, sharing the responsibilities of taxation, and developing mutual protection against the impacts of disasters among its members. There were collective funds to look after members' health needs, the needs of the most disadvantaged, and to pay for children's education. Women benefited from such collective welfare arrangements, achieving a higher level of both economic and political participation in the 1970s compared to earlier decades. Other benefits included improvements to population health, as many communicable diseases were eradicated due to rural cooperative healthcare programs (Chen and Standing 2007).

In the 1980s economic reforms, however, a transition began in government control. The state initiated the household land contract responsibility system to reorganize agricultural production in response to rising food shortages and low productivity. This system re-distributed land use to households; by offering farmers an opportunity to improve household livelihood, the state hoped that farmers would have an incentive to increase agricultural production. By the early 1980s, nearly all the communes were dissolved. Small-scale households once again became the unit of agricultural production. Productivity soon increased and harvests abounded across the country. However, this reform assigned women to a subordinate position, since it utilized the male head of household system to distribute resources, including land. It also failed (see Chen 2008: 6-7) to allow for coordinated action to build social organizations, such as farmers' 
associations or cooperatives and village women's groups, to address the gendered social impacts of this reform policy. Likewise, the reforms failed to include coordinated action to transform previous systems of food distribution. This greatly weakened the power of farmers and especially rural women.

Problems that troubled policymakers in the early 1950s remained, not least of which was linking thousands of small-scale household producers with outlets for seeds and sales of their products. Consequently, in the 1980s, the government mobilized the old Agricultural Supply and Sales Cooperatives and enacted a system of contracts. These contracts were signed between commerce departments and farmers before planting, based on sales for a fixed amount of grain, 30 percent of which was at a base negotiated price and 70 percent guaranteed at a higher price than the negotiated base price. Farmers could sell any surplus outside the contracted quota in local or more distant markets. As a result of such policies, farmers saw a 35 percent increase in the price they received for their grain products in 1984 compared to just a few years earlier, in 1979 (Zhang Xiaotao and Wang Yang 2009: 81). Just prior to this, from 1978 to 1984, China had seen grain production increase by 23 percent, from $319 \mathrm{~kg}$ per capita in 1978 to $393 \mathrm{~kg}$ in 1984. This brought China, for the first time, close to the world average. Such increases challenged the system of government control, which was based on managing low levels of consumption and food shortages.

Another major turning point came in 1985, when the State Council adopted the Ten Policies to Improve the Rural Economy (Zhang Xiaotao and Wang Yang 2009: 81-84). These ten policies brought an end to the previous unilateral system of government control. Under the "ten policies" farmers were invited to sign contracts directly with enterprises and government agencies. The so-called "dragon-head enterprises," leading processing, trade and consumption of agricultural products, often had the financial and technical support of local government offices. This subcontracting of production to small household-based farmers created multiple links in the chain of agricultural production and distribution. These chains of production and distribution link from government organizations and enterprises with government ties, such as the Agricultural Supply and Sales Cooperatives and local branches of the China Grain and Oil Group Corporation, to specialized agricultural associations, and to individual farmers (Ou Zhiwen 2008: 122). This new chain of agricultural production and distribution has been largely unfavourable to small farmers, who are in the main women and are in a weak bargaining position compared to the larger government organizations and enterprises.

In 1987, Gao Xiaomeng and Xiang Ning (1992, cited by Zhang Xiaotao and Wang Yang 2009) surveyed 93 counties and found that state-owned agricultural agencies were still the dominant force as together they controlled 55.78 percent of the total shares in the buying and selling of grain products outside of sales fixed at government-contracted prices. Zhang Xiaotao and Wang Yang (2009: 85) suggest that next to these national state-owned agricultural agencies were enterprises owned by local governments that use grain as their main raw material, with 18.04 percent of the market. The Agricultural Supply and Sales Cooperatives relatively limited influence was restricted to 7.7 percent market share, ahead of individual trading enterprises. The 
farmers, at the bottom, were organized into associations of specialized households and authorized to sign contracts with government controlled enterprises.

\section{The 1990s and 2000s: Who Shall Feed the Chinese?}

In the middle of the 1990s, the state responded to the "who shall feed the Chinese?" debate by promoting the modernization of agriculture through corporatization, while maintaining a government role in pricing and trade. The state promoted "dragon-head enterprises," mentioned briefly earlier, facilitating contracts between such enterprises and individual farmers and farmers' associations. Beginning in this period, different provinces set their own prices and policies for grain supply and storage, as the varying growth of population and rise in income demanded changes in the structure of food provision. The governor of each province was delegated responsibility for the regional structure of grain storage from cities to counties, deciding what percentage, anywhere from 18 to 30 percent, out of the province's annual output of grain would be stored. Within this provincial grain storage structure, farmers themselves were expected to be responsible for up to 70 percent of the grain storage. At the same time, in the year 2000, according Liu Qi (2012: 127-8), the government established the General Grain Storage Management Corporation, under the State Council. This grain storage was designed for military use and for emergencies.

By 2007, agricultural production, though reduced in significance as a share of the economy, still contributed 11.3 percent of the GDP and occupied 40.8 percent of the total work force in China (China Statistical Yearbook 2008). Grain production remains an important part of the Chinese economy, especially in the large agricultural provinces in central China (Hebei, Henan, Shandong, Anhui, Jiangsu, Hunan, Hubei, Sichuan) and provinces in the northeast (Heilongjiang, Jilin, Liaoning, Inner Mongolia). Indeed, these provinces together have 65 percent of the arable land, produce over 70 percent of the total grain output and provide over 80 percent of the grain marketed for consumption (Wang Guofeng 2009: 107-108). Due to poor transportation in the northeastern and the western areas as well as the loss of arable land in the south and along the east coast to urban development, grain supply has been tight to the needy south and eastern coastal areas, including Beijing, Tianjin, Shanghai, Zhejiang, Hainan, Guangdong and Fujian, western areas of Gansu, Ningxia, Shanxi, Shaanxi, Qinghai, Guizhou, Yunnan, and Chongqing. Tibet is generally self-sufficient at subsistence levels, although there may be rare periods of emergency food shortages. Emergency shortages elsewhere are typically caused by poor state management of grain markets and, to a lesser extent, transportation bottlenecks (Wang Guofeng 2009: 110-111).

Indeed, despite the government efforts initiated under the "who feeds the Chinese?" debates in the 1990s, there is little indication that there are important grain stores across the country. As Liu Qi (2012) notes from a news report by the official state paper Economic News Daily on June 14, 2011, one of the hundred highest grain production counties, Lanxi County in Heilongjiang Province in the northeast, had an annual grain output of over 1 billion $\mathrm{kg}$. Yet 
many of its grain stores are empty. Liu Qi also finds that many farmers, like those in Qide County in Anhui Province, have no capacity to store more than 300-400 kg a year, which is just enough for the family's annual consumption. Many rural families with members moving into non-agricultural production have followed urban residents in storing $5 \mathrm{~kg}$ extra staple food per person in the family. But such low capacity of grain storage at the local levels threatens food security.

So far, I have drawn a picture of changing agricultural policy in China since the Great Leap Forward. After a period of collectivization that increased bargaining power and mutual support among rural farmers, especially in the 1970s, these communes were broken up into single households, specifying a male head of household, as part of broader economic reforms in the early 1980s. Subsequently, increasing corporatization and marketization has been pursued alongside a persistent and important role for local and national governments, that still control much of the sale and distribution of grain. Although grain production increased after the communes were disbanded, it then tapered off only to improve again slightly in recent years, China has not been able to guarantee adequate storage of grains especially for emergency household use. Moreover, individualized farming households are in a weak position on local, national and international markets, with respect to much larger local, national and increasingly international buyers.

All of this has taken place in an international context unfavourable to agricultural workers. For instance, when China joined the WTO in 2001 it agreed to drastically limit agricultural subsidies, creating new hardships for farmers just when prices for agricultural inputs, like fuel, were increasing, in part due to financial speculation on these inputs. All of this has created food insecurity for household farmers by damping production and because low income from farming means that farmers have limited cash to buy supplementary, high-quality food in times of need and pay for social services. But so far, I have only hinted at the gendered nature of these dynamics. Next, I turn my attention to what these transformations have meant for rural women.

\section{Rural Women: The Lower End of the Value Chain of Production}

As indicated by a 2004 government report, 60.1 percent of employed women in China were in agriculture, 9.4 percentage points higher than men. 1999 government statistics show that these women agricultural workers invariably earned about 60 percent of what men made. ${ }^{1}$ This percentage went up as high as 68 percent in 2005 but then declined to 56 percent in $2010 .^{2}$

1 From the White Paper on China's Employment Conditions and Policies, published by the Ministry of Labour and Social Security of China in April 2004.

2 See pages 60, 63, and 65 in the National Bureau of Statistics of China (2007) and the 3rd National Survey on the Status of Chinese Women Report at http://www.wsic.ac.cn/academicnews/78621.htm, accessed on 9 August 2013. The decline of rural women's income, compared to men's, in recent years is one indication that inequality in the 
Increased world competition forced Chinese agricultural producers to reduce costs and lower prices in the early 1990s, and then in the years since 2001 when China became a member of the World Trade Organization. Since women make up the bulk of agricultural workers, they have disproportionately suffered from lower agricultural prices. But more importantly, this inequality results from rural women's increasingly unequal access to productive resources over the past decades and from unrelenting pressures on rural women in the sphere of social reproduction given persistent gendered divisions of labour.

Land, for instance, is under significant pressure given the recent, unrestrained frenzy of government appropriation for mostly commercial development. This 'land grab' may be interpreted in classical historical materialist terms as state-supported primitive accumulation, in this case through the dispossession of subsistence farmers. It represents an outright assault on farmers' rights to housing, dignity, and a decent standard of living. Although there is compensation, women are especially shortchanged largely because they tend to move in with their husbands' families after marriage. In recent years, once village women are married to someone outside their villages, their home villages erase their memberships and entitlements (see Chen 2014). Moreover, seeds, whose production and distribution have been controlled by big companies that have links with governments, continue to limit farmers' choices over decisions on production. Local governments' policies to promote lead "dragon-head enterprises," in rural restructuring further disadvantage small farmers including women. Practically, the combined results of such policies are to further gender disparities. Women are concentrated in labor intensive farming and raising animals in addition to their reproductive responsibilities in the household. In contrast, men dominate enterprises or operations in processing and sales, conferring both greater authority and better pay on men (Chen 2008: 33-34).

Rural women's position at the lower end of the value chain of production threatens food security. Given their relatively lower wages and income compared to men and given rising household costs, they frequently do not have sufficient resources to cover the costs of reproduction, including food, education and health care, and weather the impacts of economic slowdown on rural families and communities in the aftermath of the financial crisis of 2008/2009. Women and their families are vulnerable as well when recovering from natural disasters, which may be linked to climate change and other humanly created damage to the natural environment, like the widespread draughts first in the southern and then in the northern agricultural regions in 2010/2011. This is because women have little extra income against hard times and because they produce little surplus that can be saved for use against such natural disasters.

How has this situation for women come about? As already described, many state agricultural policies focus on increasing agricultural productivity, and grain supply, distribution and storage. These represent a concern from the "top" for reversing the decline of grain output and the imbalanced regional provision of staple foods. This is very far from political change from

countryside is expanding as a result of the gender-based divisions of labour in agriculture. 
"below", initiated by and for women producers. Such change from below might instead focus on increasing household income, achieving more equality between men and women, including in the sphere of the household, and improving women's wellbeing. Indeed, despite the existence since 1949 - of the official All-China Women's Federation and constitutional guarantees of gender equality, rural women have little political voice. Consequently, in recent agricultural policy, there is no recognition of the role of women as producers and providers of household food security. Ironically, this neglect of women's roles actually damages the Chinese state's efforts to achieve higher productivity.

Gendered divisions of labour, including in food provision and distribution, are not new to rural China. However, they are exacerbated by the government strategy concerning grain production and distribution in which reproduction is separated from production. This artificial separation is reinforced by a set of institutionalized rules, norms and values that govern the distribution of resources, responsibilities and power among social groups delineated by gender, class, ethnicity, and further shaped by internal migration. In this, the state occupies an overwhelmingly powerful position as it oversees the divisions of labor through its legislative, administrative and judicial arms. In favouring production at the expense of social reproduction, it adopts insensitive and even harmful policies to subordinate women and the disadvantaged, favouring production at the expense of social reproduction (Lanyan Chen 2011).

For instance, since the 1990s, some rural households which specialize in specific products have formed shareholding associations. They are able to sign contracts with enterprises and government offices, breaking through the boundaries of small scale, household-based production. There was also a movement for rural women to organize into cooperatives, as I documented earlier (Chen, 1999), which had received support from local state-sanctioned Women's Federations. However, the government's neglect of cooperatives and its control of rural financial institutions, overall, discouraged women's cooperatives and eventually led to their dissolution. Even if this was not the intention of the state policy, the consequence of the planned demise of these cooperatives has greatly weakened women's voices.

In practice, state policies have institutionalized and favoured the male head of household in the distribution of resources and services in the countryside. By failing to explicitly recognize the role of women, given a gendered division of labour, the head of household system has helped establish men's superiority in authority and wealth and enforced women's subordination and their responsibilities for reproductive labour. Furthermore, when men migrate from rural areas to the city for paid work without their wives, women are left as the de facto head of the household - responsible for work inside and outside the home. But despite this reality, women are still treated as subordinates and are given few institutional support when they try to exercise authority.

Among these responsibilities, women generally maintain household food security. According to the Food and Agricultural Organization, food security "exists when all people, at all times, have physical and economic access to sufficient, safe, and nutritious food to meet their dietary needs and food preferences for an active and healthy life" (FAO, 2013: 16-7). The 
responsibilities to safeguard food security include the provision of daily food at the household level, and the distribution of food equitably among people, regardless of economic means to pay. The issue of distributing food equitably concerns vast geographic areas, but also includes equitable distribution at the most local levels, among members of households. This household distribution of healthy food, in adequate amounts and variety, is the centre of women's concerns with family wellbeing. Yet if one of women's major tasks in china is securing food for the household, policymakers rarely recognize women's indispensable roles in the provision of daily food at the household level and in the equitable distribution of food among members of households.

Recognizing women's indispensable roles requires a feminist political economic analysis to decipher not only the impacts of policies on women but also women's potential to influence policies; such feminist analysis "makes visible" what is invisible in Chinese economic policies, including the vital relations between productive and reproductive labour and the gendered divisions of both forms of labour. What such feminist analysis shows is that the rural reform policy of household land contract responsibility, adopted at the start of the Chinese economic reforms in 1979, has failed rural women. It is true that recent policies to improve healthcare and pensions in the countryside may help relieve some burdens of care by women. For example, with respect to care for the sick and the elderly, women may experience some relief when care is provided by institutions like clinics and elderly home facilities. However, official state agricultural policies still largely ignore rural women's work, and do not address women's continued, overwhelming responsibility for housework and home-based care. In fact, widespread cases of milk powder poisoning are suggestive of the ways that rural women have been overburdened, and that they are unable to ensure food safety in the face of combined interests in profit on the part of local governments and corporations; at the same time, these cases of milk powder poisoning put new pressures on women who must strive to ensure food safety despite their multiple roles in and outside of the home (see a report, for example, at http://www.cbc.ca/news/world/china-executes-2-for-tainted-milk-powder-scandal-1.792477).

One direct measure of the enormous stress and lack of support for rural women in China is the elevated rates of suicide among these women. Indeed, suicide is the leading cause of death among rural women in China. In particular, rural women are unable to cope with rising debts given declining agricultural prices, rising production costs and the unrelenting pressures of women's everyday household labour. The widespread availability of pesticides means that suicide is a readily-available option for too many women in rural China (see, for instance: http://www.who.int/bulletin/volumes/87/12/09-011209/en/\#). As the following case studies show, however, rural women's situation is not identical across China and the variations are suggestive of ways that these women's political voice may be strengthened.

\section{A Closer Look: Case Studies of Rural Women in Contemporary China}

In the countryside of Guangdong and Fujian provinces in the southeast of grain needy 
areas, where land is scarce and is largely mountainous and rocky, and of Hebei and Shandong provinces in the central grain production areas, there are two gendered systems of agricultural production that continue to place rural women potentially at a disadvantaged position. These two trends reinforce gender inequalities, although women in the south, working in isolation, seem to face more challenges than their sisters in the central region, where the women work together and have opportunities to speak with a collective voice.

Rural women in the two southeastern provinces of Guangdong and Fujian, for instance, manage small family plots and occupy the lower end of the market chain by selling their agricultural products in local farmers' markets or to wholesalers in local wholesale markets that have been set up mostly by men to meet the needs of distant markets. Men not only control local markets but also the supply chains between local markets and retailers including big agribusiness, both domestic and transnational, such as Wal-Mart and Carrefour. In contrast, in Hebei and Shandong in the central region where it is flat, there are expanding agricultural farms run by men who have leased land from other farmers, or sometimes from women who have lost the ability to cope with the costs of farming their own lands while their husbands and children have left to work in urban areas. These women often work for the emerging larger farms on a seasonal basis, earning a daily wage. Women's income is comparatively lower than men's even though it is used more often for covering the costs of family's reproduction and grain storage in preparation for emergencies and scarcity. These disparities are serious challenges not only to rural women but also to household food security.

\section{The Cai Household}

In Fujian, for instance, Mr. Cai's household is located in a village of the Hua Ting Township in the District of Cheng Xiang, Pu Tian area. The household has three members, including his wife and daughter who studies in high school. The family has only $1.3 \mathrm{mu}$ of land (1 $\mathrm{mu}$ is about 666.66 square meters). As land is very scarce the land per capita of this village is only $0.39 \mathrm{mu}$. The land used by the family is still considered part of village property so it cannot be sold but it could be contracted out to other village members or even someone from outside the village. The land, though it is small, is still broken into smaller plots, some of which are fairly fertile as they are in the valley and others are dry as they are on the slopes of hills. The wife looks after the land, growing rice on some plots and vegetables, peanuts and fruit trees on others. The land is used all year around and so the wife has to work all year. She gets help from her daughter and husband, when he is at home, and during harvest. Her harvests are mostly for family consumption and she sells what is left, such as peanuts and fruits, to the local markets. She feeds the family everyday with the food she grows and makes herself. The government removed agricultural taxes but with the increased cost of fertilizer, she may be just be able to break even with her food production when she gets a good harvest. She also tries to cover the needs for cash through raising chickens and pigs and working as a day laborer. 
Mr. Cai travels a lot with his business of buying and selling piba and lychee and he grows mushrooms in the winter. He entered in a partnership in 2001 with four friends, with each initially pooling 50,000 yuan. They share local information with respect to harvests and market prices, and together can better expand their client base with their local contacts among villagers. They buy lychee and piba from villagers and transport them to distant wholesale markets in Fujian and even further north to Zhejiang Province. They use local women villagers, like his wife, working for a daily wage of up to 100 yuan to quickly sort their fruit by quality and load them in baskets. This is done right near the fields while still fresh. They also go to Guangdong and Guangxi to buy lychee and piba from farms and package them right by the field with the use of local female labour and transport them back to Fujian taking advantage of the fact that the fruits ripen earlier in Guangdong and Guangxi than in Fujian. They also ship to Zhejiang Province where there are major fruit wholesale markets.

In 2001 they invested in a refrigerated warehouse nearby the Zhejiang fruit markets to store fresh fruit for up to a month to wait for a better price. Mr. Cai explained that in 2001 piba and lychee started to come from Vietnam and Thailand into China at a much cheaper price after China became a member of the World Trade Organization. This drove down the local prices. Before 2001 piba was sold at a price of around 11 or 12 yuan a jin (one Chinese jin is half a kg). In 2008 at the time of my visit in early August, piba was already harvested in Guangdong and the best price he could get was 3 yuan a jin. He already lost 20,000 yuan earlier in June when he and his partners visited the same businesses in Guangdong, buying lychee, at 0.8 yuan a jin, and transporting to Zhejiang markets and selling at 3.6 or 4 yuan a jin. They did not get a high enough price to cover the costs of packaging and transportation. There was an oversupply of lychee as a result of competition from foreign imports and more people from Fujian and nearby provinces who were doing the same as they did. He did not expect much profit from sales of piba harvested in Fujian in August. Also, other types of fruits from far away places started to appear in the local markets, and consumers, even lovers of local fruits, had more choices. He was still working on schemes to earn money, including raising mushrooms when the fruit season was over, in order to finish building the house the family was living in.

Mr. Cai's household is representative of the other households in the area I visited. On the one hand, the overall story is one of increasing precariousness, as rural families try - and often do not succeed - in competing in selling produce on newly-open markets. But this is complicated by a gender-based division of labor that has developed in the household with the wife feeding the family but receiving less recognition as she contributes - at least in good times - less to the cash income needed for major expenses like their daughter's higher education.

In the Cai family, the wife's subordinate position was clearly indicated to me as she opted to stand nearby while I tried to involve her. She had no chance to address my questions since Mr. Cai always spoke as the head of the household. One influence clearly is the traditional gender-based division of labor, with the man in charge of (valued) production for a cash market and the woman responsible for (unpaid and un-valued) reproduction. Another influence is obviously the penetration of a cash-based economy where the husband as the main cash-earner is 
more valued than the wife, whose work to keep crops growing and the family fed. Ironically, Mr. Cai is more prominent in the family even when his business ventures fail, as a consequence of declining prices for fruits in an increasingly international market. In such ways, more traditional and new patterns of economic life tend to foreground men's labour and reinforce male domination within already-patriarchal households. This seems to be true even as men bring less cash into the household.

\section{The Liang Household}

Similar observations occurred at a village in Nantao Township, Nansan County, Zhanjiang City, Guangdong, which is situated on an island, with over 500 villagers in 70 households. Lack of water means the village cannot grow rice. Growing sweet potatoes as the mainstay food is the wives' work and raising pond shrimp for cash is the husbands' job. The village chief, Mr. Liang, entered into a partnership with Mr. Li, in 2001, to raise pond shrimp in a seven mu area, while his wife grew sweet potatoes on a two mu plot which was mostly for family consumption as little profit could be made by selling them. Their three adult sons were working in Shenzhen City. Mr. Liang and his partner could earn up to 180,000 yuan a year. Shrimp were profitable because the Guolian Fisheries Development Corporation in Zhenjiang (Guo Lian Shuichan Kaifa Gufen Youxian Gongsi), sells its products to North America, Japan and Korea, as its website claims, and had a processing factory on the island and purchased shrimp from the local farms. When I visited in August 2008, similar to my previous experience, the wife kept quiet, while the husband explained, among other issues, that the household did not need to store grain as they could buy whenever it is needed outside their harvest of sweet potatoes. In other words, Mr. Laing "naturally" assumed his role as the household authority, implicitly claiming that his ability to bring cash into the household mattered more than the sweet potato production of his wife. His wife did not challenge his authority, at least in my presence, perhaps in part because she worked in isolation and was therefore without the support of colleagues outside of the household - which might have given her more courage and bargaining power within the household.

\section{An Alternative?: A Local Economy Based on Cooperatives and Collective Welfare}

In these two households in Fujian and Guangdong, the wives, who worked by themselves, did not have a voice on household issues. If they were to have a chance to work together as a cooperative, like the women I saw in a specialized organic vegetable shareholding cooperative in Cangzhou, Hebei, they might find it easier to voice their opinions, both in the work outside the home and within the household. Mr. Liu, a village official, leased $200 \mathrm{mu}$ from other villagers to create this shareholding cooperative to meet the growing urban market demands for organic produce. The shareholding cooperative hired local villagers to work in three departments, growing, packaging, and serving in the cooperative's restaurant. The women who worked in 
administration and marketing had higher wages and a better education than those in these three departments. Out of the twenty workers growing vegetables, for example, fifteen were women working eight hours a day at a rate of 8 yuan an hour. These women had largely rented out their family contracted land and earned an income supplementing the family income, while their husbands worked in nearby cities. As I talked to them while they were working in the vegetable fields, the women villagers expressed their concern with rising food prices. These women's voice of concerns for food prices would likely produce pressure which would be felt by village leaders including Mr. Liu, who was trying to use the shareholding cooperative to spin off more projects to contribute to the village's collective coffer to pay for cooperatively based healthcare and pension for the villagers.

The women in the Ri Sheng Cooperative in Lianjiang, Guangdong, are another example where they are visible and have a voice. The Ri Sheng Cooperative is an association of specialized households in the production and marketing of lychee and piba. It was founded in 2003, three years before the adoption of the Law on Farmers' Specialized Cooperatives of the People's Republic of China, with twenty households of lychee and piba growers, pooling 500,000 yuan together to find new ways collectively to market their products. It grew to include 302 households spreading from Lianjiang into different cities including Suixi, Wuchuan, and Moning in Guangdong in 2008. Some of the households managed as many as $1000 \mathrm{mu}$ for growing fruits. Most households had between 30 and $50 \mathrm{mu}$. In 2007, the cooperative had a total output of 7000 tons of lychee and 1000 tons of piba. The cooperative had its own trademark - "Guang Liang," granted by the government agency for its environmental friendly quality. Under this brand it not only supplied its fruits directly to Chinese supermarkets but also exported them to North America and other countries. The cooperative was able to secure export and domestic markets in such a short time, despite heightening competition, because when the cooperative office gets an order, it quickly sends out the information on the quality, amount, timing and locations of the order to its members and organizes transportation and packaging quickly to meet the order. The member households coordinated on questions of when to fertilize and water as well as in other technical aspects of production through an online platform operated by the cooperative with the support of the local telecommunication company. It used the electronic platform to disseminate management decisions, technical information with respects to pest control, weather broadcasting, marketing information and business plans. It hires local village women, who were not necessarily members, as day laborers at 100 yuan a day to sort and package fruits for each order.

The cooperative works on a member assembly system where major decisions on fees for services and the use of profits are adopted based on one household, one vote. At the assemblies, both husbands and wives attend as the wives are the ones spending the most time in looking after the fruit trees and have the technical expertise and also need to receive any new technical information first hand. Though the director and two vice directors of the cooperative were men, there were several women working in the marketing and accounting departments at the time of my visit on August 5, 2008. They spoke with authority on the conditions of markets as they saw them at the time, while the directors listened. In other words, because they worked in a 
cooperative and had to be knowledgeable (about weather conditions, prices, production etc.) and share their knowledge (about their work), their role in agricultural production - which was invisible to patriarchal household heads in the cases of Mr. Cai and Mr. Laing - became visible. In fact, these women's labour and knowledge about their work was visible in the whole cooperative. This gave them a voice and authority that many rural women in china do not have, in their workplace or in their homes.

\section{Conclusion: Giving Voice to Rural Women}

In China, the rural women who work on the land, with or without their husbands' help, are disadvantaged in their access to resources. They are similarly disadvantaged in their participation in markets as they occupy the lower end of the value chain of agricultural production. In short, they are battling with inequalities in an increasingly cash-based market economy and struggling because they work in isolation and are not well organized. This lack of organized solidarity among rural women translates into limited bargaining power against male-dominated wholesalers and ultimately international agribusinesses and big retailers.

Their isolation, as illuminated by the relative voicelessness of the women I interviewed in Fujian and Guangdong, reinforces women's oppression in the family and the community. This means that although women are responsible for reproductive labor, which is critical for family wellbeing and household food security, and for much of the productive labour, they have little authority. In recent decades, the corporatization and marketization of agriculture in China, which might have been done in more gender-equal ways, has instead furthered gender inequality and increased women's oppression. Rural women are disenfranchised on issues relating to the production, distribution and storage of grain, the very issues that are at the center of current public discussions of food security. The consequence is a vicious circle: rural women's voices have been ignored in political and policymaking discussions that vitally concern them, with the result that their lives have been made more difficult after reforms. At the same time, because they are now increasingly overburdened and under-valued as a result of the reforms, their political power is further reduced and they have greater difficulty in making their concerns heard.

To change the course of policies - and more broadly of politics - around agricultural production that disadvantage rural women, mechanisms are required to advance their participation in economic and political processes on an equal footing with men. I strongly suggest the promotion of women's cooperatives in order to help them gain a collective voice in influencing decisions on agricultural production, distribution and storage. When women collectively work together, they have opportunities to share experiences and ideas, so improving both economically and socially. Cooperatives thus represent an important way for rural women to turn their concerns into joint efforts to build collective welfare and to influence policies to be more sensitive to meeting their gendered needs. Such gendered needs include rural women's demands for access to productive resources including land, credits, knowledge and organization of information and cooperation. They must also move up the value chain of agricultural 
production and distribution to deal directly with players that influence markets, including wholesalers, national and transnational corporations.

Some socialist feminist might object that I am just advocating for women to play a bigger role in an unjust and exploitative capitalist system. I would argue that these efforts matter in terms of improving rural women's wellbeing in the immediate term, not least by helping women day laborers have a stronger collective voice that may enable them to guarantee basic food security. Moreover, there are broader political implications of rural women finding a collective voice through cooperatives. If they can gain some political weight by organizing cooperatively, they can begin to influence decision-making at the level of local planning of agricultural production and distribution.

If cooperatives like the Ri Sheng Cooperative in Lianjiang, Guangdong, could persuade the local governments to accept cooperatives as a category of licensed businesses, they could also find ways to compete in markets. This is not just about "being competitive" - it is about better pay for rural women's labour and agricultural production and it is intimately tied to these women's welfare and the welfare of their families. Moreover, such cooperation might also allow women to develop ways to store grain collectively in support of food security. They would certainly be in a better collective position to create new pressures for socially equitable programs with respect to rural healthcare and pension. Collective wellbeing depends on a political voice for women; cooperatives are one way that rural women in China can begin to develop that critical voice.

\section{References}

Chen, Lanyan, (2014) "From Chinese State Capitalism to Women's Activism: The Implications of Economic Reforms for Women and the Evolution of Feminist Organizing," available at http://www.oxfordhandbooks.com/view/10.1093/oxfordhb/9780199943494.001.0001/oxf ordhb-9780199943494-e-020?rskey=UWpyom\&result $=1$.

Chen, Lanyan, (2011) "Equity in Post-Crisis China: A Feminist Political Economy Perspective." Pp. 249-266 in Devaki Jain and Diane Elson, eds. Harvesting Feminist Knowledge for Public Policy: Rebuilding Progress. Ottawa \& Los Angeles: IDRC and Sage.

Chen, Lanyan, (2009) “The gendered reality of migrant workers in globalizing China." Pp. 186-207 in Mendes, Errol P. and Sakunthala Srighanthan, (eds.) Confronting Discrimination and Inequality in China: Chinese and Canadian Perspectives. Ottawa: University of Ottawa Press.

Chen, Lanyan, (2008) Gender and Chinese Development: Towards an Equitable Society. Routledge. 
Chen, Lanyan and Standing, Hilary, 2007. "Gender equity in transitional China's healthcare policy reforms." Feminist Economics. 13(3-4): 189-212. July/October.

Chen, Lanyan, (1999) “Expanding women's cooperatives in China through institutional linkages." Development and Change. 30(4): 715-38.

China Statistical Yearbook 2008. Accessed on August 20, 2009. http://www.stats.gov.cn/tjsj/ndsj/2008/indexch.htm

Department of Social, Science and Technology, National Bureau of Statistics of China, Women and Men in China: Facts and Figures (2012).

Food and Agriculture Organization, The State of Food Insecurity in the World, 2013. Accessed on August 12, 2013 at http://www.fao.org/docrep/018/i3434e/i3434e00.htm.

Food and Agriculture Organization, (2003) Trade Reforms and Food Security: Conceptualizing the Linkages. Accessed on October 10, 2013, http://www.fao.org/docrep/005/y4671e/y4671e06.htm\#TopOfPage

Food and Agriculture Organization, The State of Food and Agriculture 2010-11: Women in Agriculture, Closing the Gender Gap for Development. Accessed on August 10, 2013, at http://www.fao.org/publications/sofa/en/

Freeman, Will, 2010. The accuracy of China's 'mass incidents.' Financial Times. 2 March.

Gao Xiaoxian, (2006) Zhongguo Shehui Zhuanxing: Nongcun Funv Yanjiu (Chinese Social Transformation: Rural Women). Xian: Shanxi Renmin Chubanshe (Shanxi People's Publishing House).

Gong, Peixing, (2011) Jiedu “12'5” Nongmin Zengshou Xinzheng (Interpreting the New Policies to Promote Farmers' Income during the 12th Five Year Plan). Nanchang: Jiangxi People's Publishing House.

$\mathrm{Hu}$, Ruifa, Cheng Jia-an, Dong Shouzhen and Sun Yinyin, (1998) "Funv zai Nongye Shengchanlizhong de Jueze Xingwei ji Zuoyong" ("Women's Decision-Making in Agricultural Production”). Nongye Jingji Wenti (Agricultural Economic Issues). 3: 52-4.

Hu, Yuanyuan, (2004, 15 December) 'Agricultural sector facing pressure', China Daily, p.11. 
Jacobs, Andrew, 2011. Farmers in China's south riot over seizure of land. New York Times. 24 September. Accessed at http://www.nytimes.com/2011/09/24/world/asia/land-dispute-stirs-riots-in-southern-chi na.html? $\mathrm{r}=0$, on 5 August 2015.

Liu, Qi, (2012) Zhongguo Sannong Wence: Nongcun, Nongye (China Three Rural Problems and Strategies: Countryside and Agriculture, Vol. II). Hefei: Anhui People's Publishing House.

Nie, Yonghong, (2009) Zhongguo Liangshi Zhilu (China's Food Provision). Beijing: Economy and Management Publishing House.

Ou, Zhiwen, (2008) Nongye Liutong Lingyu Hezuo Jingji Zuozhi Yanjiu (Economic Cooperative Organizations in Agricultural Production and Marketing). Changsha: Hunan University's Publishing House.

Report on Major Results of the 3rd Survey on the Social Status of Women in China, (2011, October 21) Published by the All-China Women's Federation, National Bureau of Statistics of China. http://www.wsic.ac.cn/academicnews/78621.htm, accessed on August 9, 2013.

Sun, Nancy, 2013. "Rural Women in Landless Limbo." Available at http://www.womenofchina.cn/html/womenofchina/report/168421-1.htm, accessed on February 6, 2014.

Wang, Guofeng, (2009) Zhongguo Liangshi Zonghe Anquan Tixi Yanjiu (Research on the Food Security Integrated System of China). Beijing: China Economic Publishing House.

Yin, Chengjie, (2009) Liangan Tianxia: Quanqiu Liangshi Weiji yu Zhongguo Liangshi Anquan (Food Security, Global Stability: Global Food Crisis and Food Security in China). Beijing: China Economic Publishing House.

Zhang, Chunni, Qi Xu, Xiang Zhou, Xiaobo Zhang, and Yu Xie, 2013. “An Evaluation of Poverty Prevalence in China: New Evidence from Four Recent Surveys.” IFPRI Discussion Paper 01293. September. Development Strategy and Governance Division.

Zhang, Liguo, 2008. Liangshi Anquan Beijing xia Woguo Liangshi Zonghe Shengchan Nengli Yanyiu (Study of China's Overall Food Productivity under the Background of Food Security). Beijing: Zhongguo Nongye Chubanshe (The Publishing House of Chinese Agriculture). 
Zhang, Xiaotao and Wang, Yang, (2009) Daguo Liangshi Wenti: Zhongguo Liangshi Zhengce Yanbian yu Shipin Anquan Jianguan (Large Country Grain Issue: China Grain Policy Evolution and Food Safety Administration). Beijing: Economy and Management Publishing House. 